\section{High-Resolution Lidar Topography of the Puget Lowland, Washington - A Bonanza for Earth Science}

\author{
Ralph A. Haugerud, rhaugerud@usgs.gov, U.S. Geological Survey, c/o Department of \\ Earth and Space Sciences, Box 351310, University of Washington, Seattle, Washington \\ 98195, USA
}

David J. Harding, david.j.harding@nasa.gov, National Aeronautics and Space Administration, Code 921, Goddard Space Flight Center, Greenbelt, Maryland 20771, USA

Samuel Y. Johnson, sjohnson@usgs.gov, U.S. Geological Survey, P.O. Box 25046, Lakewood, Colorado 80225, USA

Jerry L. Harless, jharless@psrc.org, Puget Sound Regional Council, 1011 Western Ave, Suite 500, Seattle, Washington 98104, USA

Craig S. Weaver, craig@usgs.gov, and Brian L. Sherrod, bsherrod@usgs.gov, U.S. Geological Survey, c/o Department of Earth and Space Sciences, Box 351310, University of Washington, Seattle, Washington 98195, USA

\section{ABSTRACT \\ More than 10,000 $\mathrm{km}^{2}$ of high-resolu- tion, public-domain topography acquired by the Puget Sound Lidar Consortium is revolutionizing investigations of active faulting, continental glaciation, landslides, and surficial processes in the seismically active Puget Lowland. The Lowland-the population and economic center of the Pacific Northwest - presents special prob- lems for hazards investigations, with its young glacial topography, dense forest cover, and urbanization. Lidar mapping during leaf-off conditions has led to a de- tailed digital model of the landscape be- neath the forest canopy. The surface thus revealed contains a rich and diverse record of previously unknown surface-rupturing faults, deep-seated landslides, uplifted Holocene and Pleistocene beaches, and subglacial and periglacial features. More than half a dozen suspected postglacial fault scarps have been identified to date. Five scarps that have been trenched show evidence of large, Holocene, surface- rupturing earthquakes.}

\section{INTRODUCTION}

Whether looking for active faults, modeling flood inundation, inventorying landslides, or mapping bedrock geology, earth scientists depend on topographic data. In 1997, geologists in the Puget Lowland got their first look at a detailed lidar (light detection and ranging, also known as ALSM or airborne laser swath mapping) topographic survey. Using a narrow laser beam to probe through the trees, lidar can produce accurate terrain maps even where forest cover stymies traditional photogrammetry. The survey was commissioned by Kitsap Public Utility District to map groundwater infiltration and runoff on Bainbridge Island, just west of Seattle (Harding and Berghoff, 2000). Among the landforms portrayed was a 1-5-m-high, east-trending scarp that offsets north-south glacial grooves at the south end of the island, within the Seattle fault zone (Fig. 1). Previous routine topographic mapping, geologic mapping, and examination of aerial photographs had failed to identify this scarp concealed beneath dense secondand third-growth forest. Subsequent trenching of the scarp confirmed that it formed during one or more large, Holocene, surface-rupturing earthquakes (Nelson et al., 2002). This discovery quickly led to the realization that other fault scarps might be revealed with lidar.

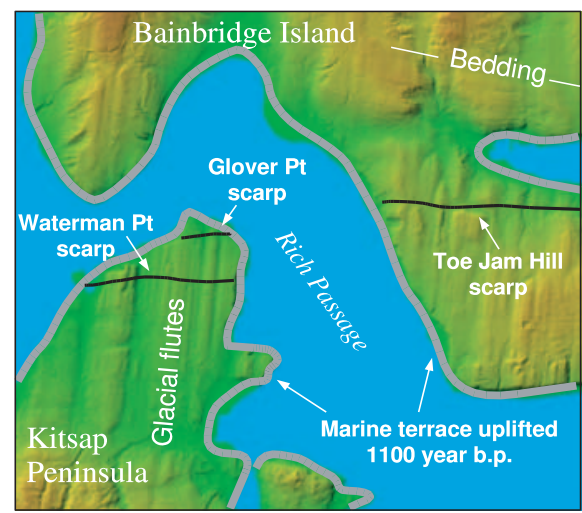

Figure 1. Image calculated from lidar topography of part of the Seattle fault zone, $15 \mathrm{~km}$ west of Seattle. Scene is $4.5 \mathrm{~km}$ across. See Figure 3 for location.
In 1999, geographic information system (GIS) specialists, planners, and earth scientists working for local government agencies, the U.S. Geological Survey (USGS), and the National Aeronautics and Space Administration (NASA) formed the Puget Sound Lidar Consortium (PSLC) and began an experiment to purchase cooperatively high-resolution, public-domain lidar topographic survey data. The initial impetus behind this effort was to find fault scarps for seismic hazards studies. To date, the PSLC has acquired over $10,000 \mathrm{~km}^{2}$ of high-resolution digital elevation models (DEMs) of the heavily forested Puget Lowland of western Washington, and we have discovered more than half a dozen scarps of possible tectonic origin. The experiment has been a success.

In this report, we describe some of the hazards facing the Puget Lowland, lidar mapping technology, the PSLC data collection effort, and our use of these data for identifying seismic hazards and for geomorphic mapping.

\section{THE PUGET LOWLAND}

Seattle and the surrounding Puget Lowland lie in the forearc of the Cascadia subduction zone (Fig. 2). Two hundred kilometers to the west, off the Pacific coast, the Juan de Fuca plate subducts northeast beneath the North American plate at $\sim 4 \mathrm{~cm} / \mathrm{yr}$. To the east of Seattle rise active volcanoes-Mount Rainier, Glacier Peak, and Mount Baker-of the Cascade volcanic arc. The Olympic Mountains to the west of Seattle are a rapidly uplifting forearc high. Between the Cascades and the Olympics lies the Puget Lowland (Fig. 3), part of a broad forearc depression that extends from southern British Columbia to west-central Oregon.

The Puget Lowland is subject to seismic shaking from great megathrust subduction earthquakes, most recently in 1700 A.D.

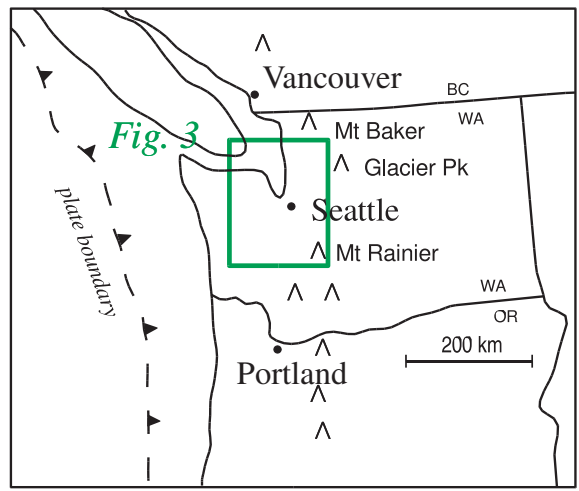

Figure 2. Location of Puget Lowland. 
(Satake et al., 1996), and from WadatiBenioff zone intra-slab earthquakes, 30-80 km deep, such as the M 6.8 February 2001 Nisqually earthquake. Faults in the continental crust pose an additional seismic hazard. These faults accommodate deformation of the forearc as it migrates north and is compressed against the older, relatively immobile crust of the Canadian Cordillera (e.g., Wells et al., 1998; McCaffrey et al., 2000). Geodetic studies (Mazzotti et al., 2002; Miller et al., 2001) indicate western Washington is shortening north-south at 3-7 mm/yr. Bucknam et al. (1992) described evidence for a shallow earthquake within the east-west Seattle fault zone (Blakely et al., 2002) about 1100 years ago. As much as $7 \mathrm{~m}$ uplift near Seattle accompanied this $\sim \mathrm{M} 7$ event. Were such an earthquake to occur today, the damage would be immense. Estimating the frequency of such crustal events is critical to assessing Seattle's seismic hazard.

Repeated, extensive, Pleistocene glaciation has obscured tectonic features in the Puget Lowland. The most recent ice sheet to flow south from British Columbia reached Olympia, $80 \mathrm{~km}$ south of Seattle, about 16,400 calendar years ago, then retreated rapidly, leaving the Lowland ice-free by 15,000 years ago (Porter and Swanson, 1998). The landscape of the Lowland still largely reflects glaciation: Much of the Lowland is a low-relief plain at an elevation of 100-150 m, formed as the floor of a broad outwash valley in front of the advancing ice sheet (Booth, 1994). Elongate, mostly north-south flutes (Figs. 1 and 3) decorate this surface, recording the direction of ice flow for the $1-4 \mathrm{k} . \mathrm{y}$. duration of glaciation. Large troughs that now contain Puget Sound, Hood Canal, Lake

Washington, and other waterways are attributed to erosion by subglacial drainage (Booth, 1994).

Regional geophysical studies (Danes et al., 1965; Blakely et al., 1999; Brocher et al., 2001) have outlined major possible fault zones beneath the glacial deposits, but are typically unable to provide direct evidence for the existence of a fault or the history of recent faulting necessary to estimate seismic hazard. One way to obtain such history is to trench fault scarps and date offset soils and scarp colluvium. However, the observed strain rate suggests postglacial fault scarps may be no more than a few meters high. Finding such scarps beneath the dense forest canopy

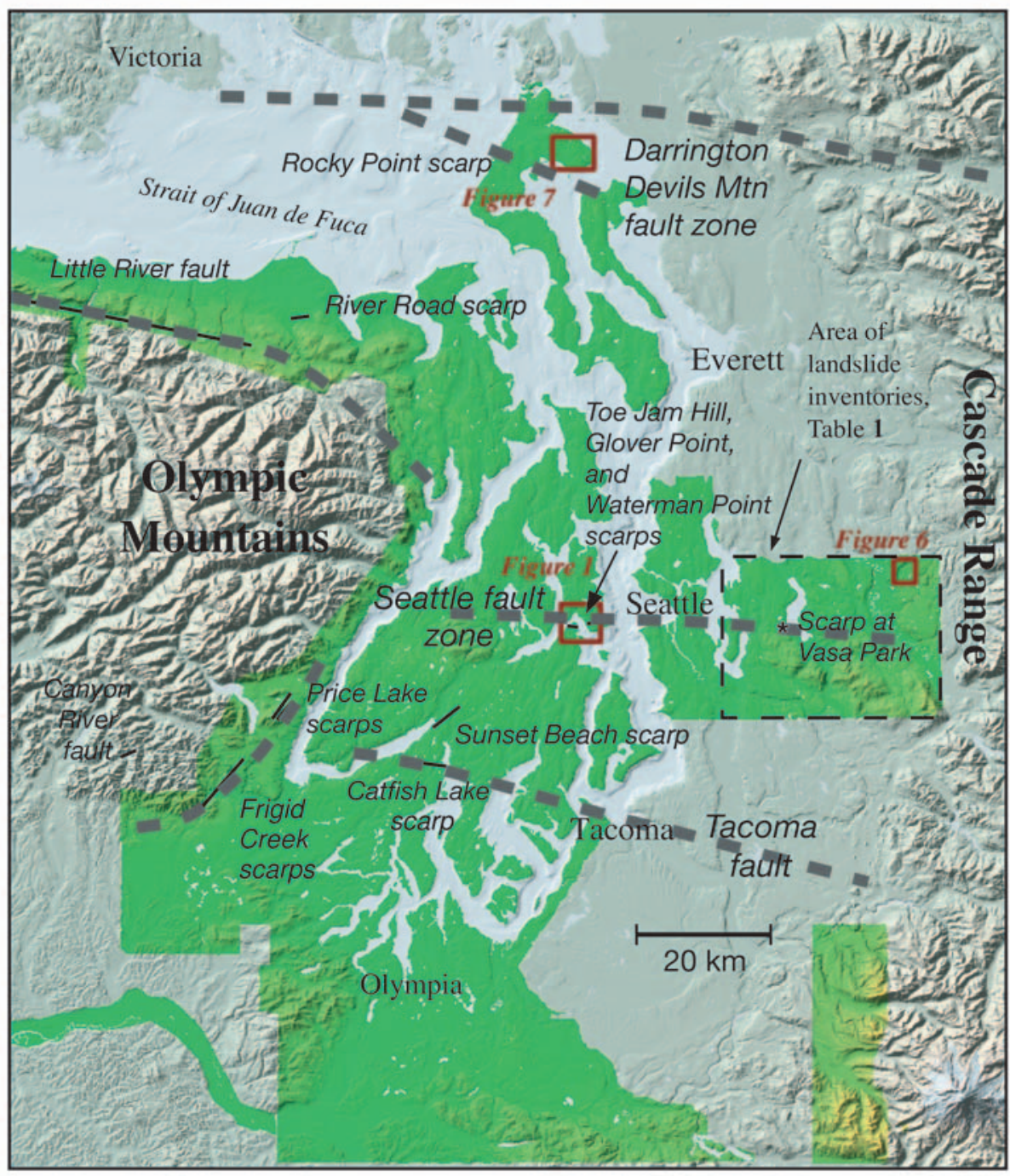

Figure 3. Map of Puget Lowland with extent of Puget Sound Lidar Consortium data as of April 2003 (darker green).

has been almost impossible using traditional photographic and photogrammetric methods. Marine shallow seismic-reflection surveys (Johnson et al., 1999, 2001a, 2001b) have identified faults with probable Quaternary offsets, but tracing these faults onshore has been difficult. The only Holocene fault scarps recognized in the Lowland prior to 1997 are at Price Lake, $70 \mathrm{~km}$ southwest of Seattle (Wilson et al., 1979).

Lidar can find these postglacial fault scarps hidden beneath the trees.

\section{ABOUT LIDAR}

Essential elements of a lidar mapping system are a scanning laser rangefinder mounted in an aircraft, differential Global Positioning System (GPS) to locate the aircraft, and an inertial measurement unit (IMU) to measure aircraft orientation (e.g.,
Carter et al., 2001). The rangefinder determines distance to a target by timing the round-trip travel of a short-duration laser pulse. The reflected pulse may produce more than one return if the laser beamwith an on-ground diameter of $0.2-1 \mathrm{~m}-$ hits more than one vertically distinct target, as in a forest. Initial processing reduces data from the three subsystems to XYZ COordinates for each discrete return. Further, largely automatic, processing-commonly referred to as post-processing-is necessary to separate ground returns from canopy returns in forested areas (Fig. 4; Haugerud and Harding, 2001).

Lidar is an attractive topographic mapping tool for three reasons. First is accuracy, with routine $10-20 \mathrm{~cm}$ height (Z) errors in unvegetated low-slope terrain. The error associated with range measure- 
ments is small: most of the Z error typically associated with lidar systems is GPS and orientation error. Position (XY) errors, primarily due to errors in laser beam orientation, can be a factor of 10 larger, and on steep slopes these errors translate into larger $Z$ errors. In densely vegetated terrain, $Z$ errors of lidar digital elevation models (DEMs) can be large (although less than that of photogrammetric DEMs) where the density of ground returns is low and vegetation returns are misclassified as ground returns. Over the next few years, advances in detection of low-energy ground returns, GPS and IMU calibration procedures, and return classification should significantly reduce errors. The second reason is productivity: measurements are made at rates of 10,000-80,000 laser pulses per second. Finally, lidar is monoscopic and provides its own illumination. These characteristics overcome the major liabilities of photogrammetry in forested terrain.

There is a growing lidar mapping industry, with more than 30 commercial instruments active in North America (see http://airbornelasermapping.com for a summary). NASA operates several research instruments (Krabill et al., 1995; Blair et al., 1999; Wright and Brock, 2002; Degnan et al., 2002), and the University of Texas and University of Florida operate lidar mapping instruments (Gutierrez et al., 1998; Carter et al., 2001). Earth-science applications of lidar mapping include coastal change studies (Sallenger et al., 1999), landslide analysis (Dietrich et al., 2001), and fault mapping (Hudnut et al., 2002).

\section{PUGET SOUND LIDAR CONSORTIUM}

The Puget Sound Lidar Consortium came together in response to (1) the discovery of a Holocene fault scarp on the initial Bainbridge Island lidar survey; (2) appreciation by local planners, GIS professionals, and earth scientists of the utility of high-resolution topography; (3) the ability of the USGS, founded on relationships built in the course of operating the regional seismograph network, to provide a common focus that enabled local agencies to work together; and (4) a grant from NASA to purchase lidar data for investigation of earthquake hazards. Kitsap County has since received federal community assistance grants to support lidar data acquisition. Local and state governments and NASA have provided additional funds for a total to date of $\sim \$ 2.5$ million.
Some PSLC members are planners and GIS staff with local government; others are federal research scientists. Our organizational structure is no more than a volunteer coordinator, an e-mail list, and a purchase contract. This flat structure has encouraged technical awareness on our part (e.g., Haugerud and Harding, 2001) and insight by the vendor into our needs. A shared high level of GIS expertise, few management constraints, lack of conflicting agency mandates, and a strong sense of cooperative purpose have all contributed to our ability to work together.

We have contracted for surveys with a nominal pulse density of $1 / \mathrm{m}^{2}$. We purchase four data layers: (1) all lidar returns, with XYZ coordinates, GPS time, return number, and off-nadir angle for each return; (2) XYZ coordinates for all returns identified as from the ground; (3) a 6-ft DEM of the lidar 1st-return surface (essentially a canopy-top model); and (4) a 6-ft DEM of the bare-earth surface (vegetation and buildings removed). Independent ground control points in open areas show vertical accuracy of $13-17 \mathrm{~cm}$ root mean square error. Limited tests in forested areas show increased vertical errors, with the DEM locally biased upward. All data are in the public domain. (For access to PSLC data, contact Diana Martinez at the Puget Sound Regional Council, dmartinez@ psrc.org. Sample data, images, and further information on the PSLC are online at http://pugetsoundlidar.org.)

\section{SEISMIC HAZARDS STUDIES Finding Faults}

To date, lidar topographic data have revealed surface ruptures along five known fault zones: the Seattle fault zone, Tacoma fault, Darrington-Devils Mountain fault zone, the northern margin of the Olympic Mountains, and the southeastern Olympic Mountains (Fig. 3).

The Toe Jam Hill scarp revealed by the initial Bainbridge survey is north-side-up, opposite the vergence suggested for the Seattle fault (Johnson et al., 1994; Blakely et al., 2002). The scarp may have formed along a backthrust within the Seattle fault zone. Trenching across the scarp in 1998 and 1999 revealed a north-dipping thrust fault that disrupts late Holocene soils. Soil stratigraphy and radiocarbon ages suggest as many as three surface-rupturing earthquakes in the past 2500 years (Nelson et al., 2002). Southwest of the Toe Jam Hill scarp, across Rich Passage, we found the en echelon, west-trending Waterman Point scarp and Glover Point scarp. Both are north-side-up. Three trenches excavated across the Waterman Point scarp in August 2001 exposed a north-dipping fault, on which Oligocene bedrock is thrust south over late Holocene soil. Radiocarbon ages from these soils indicate that faulting occurred $\sim 1100$ years ago, perhaps in the same event as rupture on the Toe Jam Hill scarp. It is interesting to note that lidar topography suggests that the Toe Jam Hill scarp does not offset an 1100-year-old uplifted wave-cut platform, while the Waterman Point and Glover Point scarps clearly offset the same 1100-year-old uplifted platform. This implies at least two closely spaced events about 1100 years ago. A north-side-up scarp is also evident in West Seattle, where it cuts the 1100year-old platform.

Several en echelon north-side-up scarps that are collectively called the Catfish Lake scarp lie along the trace of the Tacoma fault. Existence of the Tacoma fault was previously hypothesized on the basis of large-amplitude gravity, aeromagnetic, and seismic-velocity anomalies (Brocher et al., 2001), shallow marine seismic reflection surveys (Johnson et al., 2001a), glaciolacustrine strandlines (Thorson, 1989), and coastal marsh stratigraphy (Bucknam et al., 1992). Preliminary work, including a trench excavated in October 2002, suggests that the Catfish Lake scarp formed during an earthquake on the Tacoma fault $~ 1100$ years ago. North of the Catfish Lake scarp, en echelon segments of the southeast-sideup Sunset Beach scarp extend $\sim 4 \mathrm{~km}$ along a northeast trend. The scarp is as high as $8 \mathrm{~m}$. To the southwest, this feature merges with the head scarp of a large, previously undescribed landslide. Possibly the entire feature is the head scarp of an unusual, even larger landslide that rotated clockwise about a vertical axis, though this appears unlikely. Planned excavations across the scarp may resolve this uncertainty.

On northern Whidbey Island, at the south margin of the broad DarringtonDevils Mountain fault zone, we found the west-northwest-trending Rocky Point scarp. It lies along a fault strand previously defined on the basis of marine seismic reflection data (Johnson et al., 2001b). Two trenches excavated across the Rocky Point scarp in August 2002 exposed evidence for late Holocene vertical and left-lateral offset. 


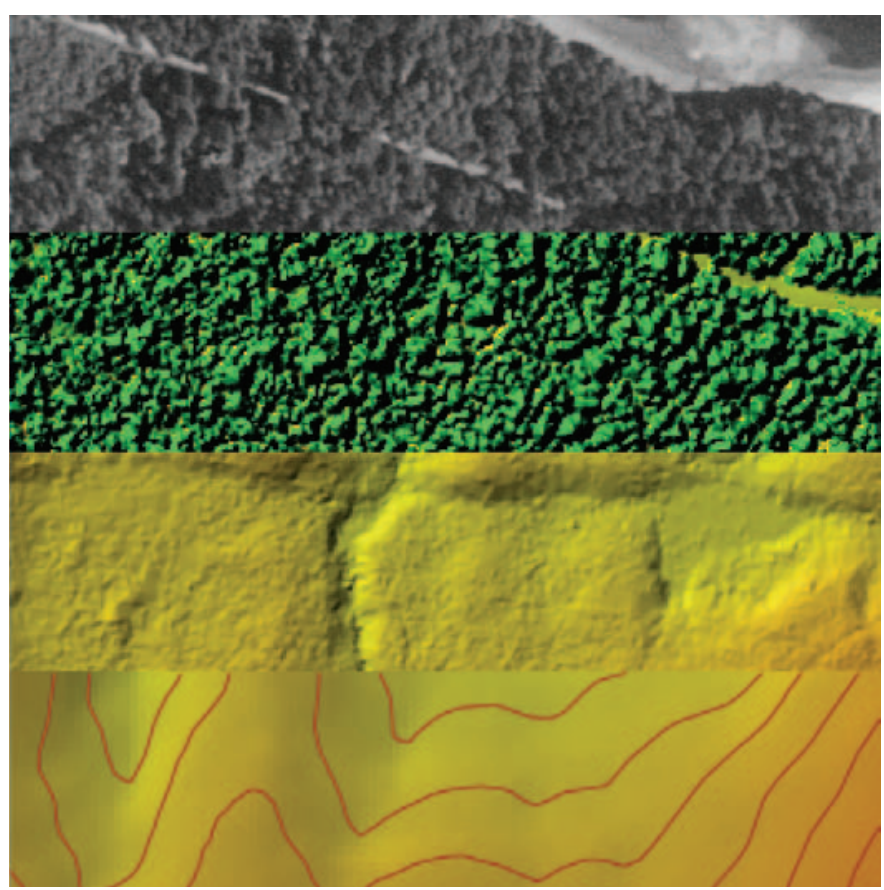

Figure 4. Contiguous image-maps, from $\mathrm{N}$ to $\mathrm{S}$ : digital orthophoto $(3 \mathrm{ft}$ pixels); lidar 1st-return surface (6-ft postings); lidar bare-earth model after post-processing to segregate ground returns (6-ft postings); U.S.

Geological Survey 10-m digital elevation model with 10-ft 1:24,000scale contours. East-west features are shoreline (upper right), a county road (upper left to mid-right), and Toe Jam Hill fault scarp (lower middle). Note disagreement on stream location. View is $600 \mathrm{~m}$ wide.

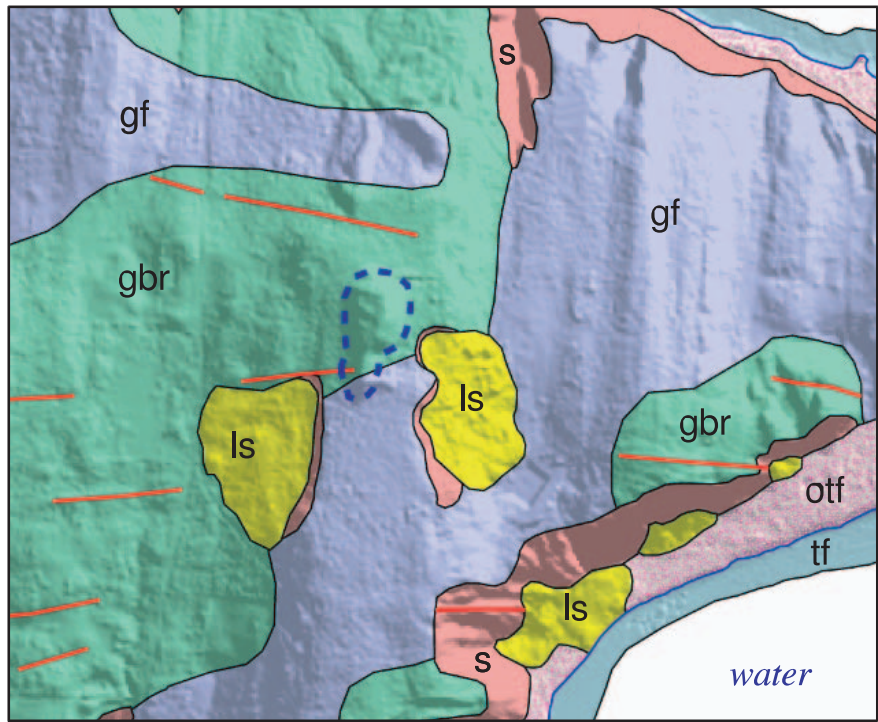

Figure 5. Geomorphic map of part of Bainbridge Island. Base is detailed lidar topography. Map units: s—scarp; Is—landslide; tf—tideflat; otf—old tideflat; gf-fluted glaciated surface; gbr—glaciated bedrock surface. Red lines are bedding traces; blue dashed line is relict shoreline from lateglacial lake. View is $1.5 \mathrm{~km}$ wide.
At the north margin of the Olympic Mountains, scarps along the Little River fault extend over $30 \mathrm{~km}$ east-west (Haugerud, 2002). At its west end, topographic features are ambiguous: a 10-20 m high southside-up scarp in bedrock suggests this is a fault-line scarp eroded along an older weakness, although surface offset within a Holocene landslide suggests young deformation. At the east end of the Little River scarp, a 1-2 m north-side-up offset of the late Pleistocene glacially fluted surface almost certainly records postglacial faulting Farther east, the River Road scarp is a minor north-side-up warp of a latest Pleistocene or early Holocene fluvial surface.

At the southeast corner of the Olympic Mountains, lidar topography images the previously recognized (Wilson et al., 1979) southeast-side-up scarps at Price Lake, and shows that the scarps are longer and more numerous. The $\sim 10-\mathrm{km}-$ long, en echelon Frigid Creek scarps cut across Holocene alluvial fans in a zone that extends southwest from Price Lake. Beyond the extent of our lidar data, the Canyon River fault has $\sim 2$ m of Holocene offset (Walsh et al., 1999). Scarp geometry suggests reverse and strike-slip motion on the Price Lake,
Frigid Creek, and Canyon River structures. Not all scarps are obvious on the lidar images. A postglacial scarp found by field investigations near Vasa Park east of Seattle (Sherrod et al., 2001; Sherrod, 2002) is poorly defined by the lidar topography. This scarp may be older than the otherspossibly 10,000 years old-and hence degraded and less distinct. Human modification of the landscape has obscured a possible extension of this scarp to the west. Most importantly, dense understory vegetation at this locale prevented the laser from imaging the ground surface. At other locales, the lidar topography is ambiguous and further investigation is required. Lidar topography is, however, localizing these investigations.

The fault scarps we are discovering with lidar strongly support a tectonic model in which reverse and oblique-slip movements along multiple faults accommodate north-south shortening of the Puget Lowland (Wells et al., 1998).

\section{Uplifted Marine Platforms}

Harding et al. (2002) used lidar topography to delineate and measure the elevation of the back edge- - the "shoreline angle" —of an uplifted, wave-cut marine platform associated with uplift on the Seattle fault zone 1100 years ago (see Figure 1). Extensive north-south shorelines of Puget Sound yield a record of the spatial pattern of uplift across the zone. There is significant structure within the uplift pattern: elevations of the shoreline angle describe en echelon, east-west anticlines $2-5$ $\mathrm{km}$ wide with limbs that dip $0.1^{\circ}-0.8^{\circ}$. Anticlines are located above the blind, basal thrust of the Seattle fault zone, with hinges uplifted by as much as $9 \mathrm{~m}$. Inflections in elevation of the shoreline angle on the south limbs suggest deformation also occurred above structurally higher blind thrusts that have been imaged in seismic reflection profiles (Johnson et al., 1999). The Waterman Point and Glover Point backthrusts, which rupture the platform, are parallel to the anticline axes.

\section{GEOMORPHIC MAPPING}

Geomorphic mapping can help in reading geologic history, inferring the properties of earth materials, and analyzing landscape evolution. High-resolution lidar topography is ideal for detailed geomorphic mapping, as the resolution of 1-2 m 


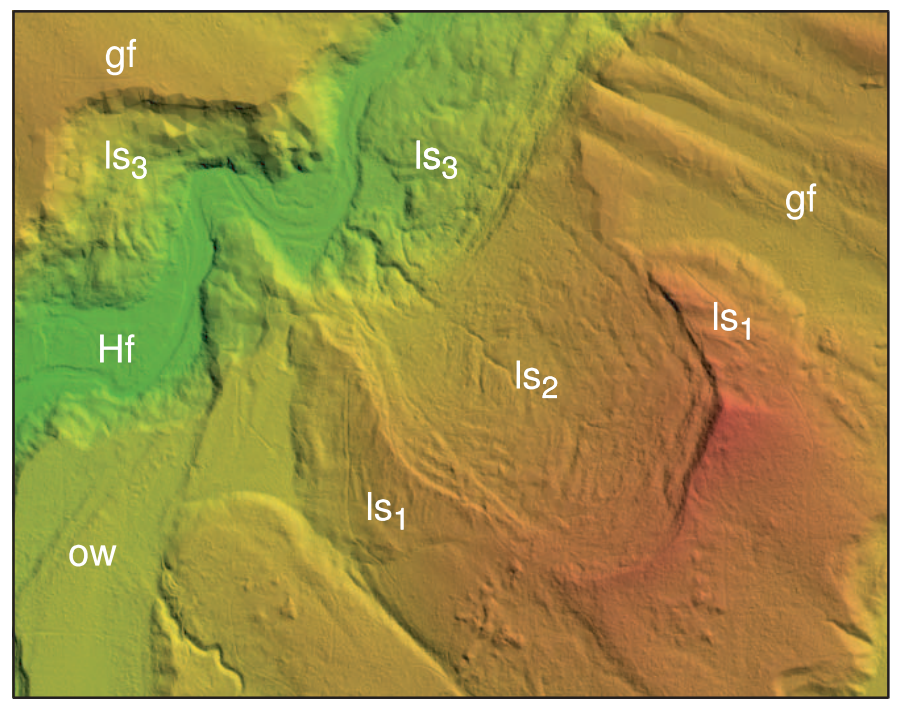

Figure 6. Lidar topography of landslides along Tolt River, east of Seattle; see Figure 3 for location. View is $3.5 \mathrm{~km}$ wide. Geomorphic units are gf-glacially fluted surface; ow-glacial outwash surface; Is—landslide, 1 (oldest) to 3 (youngest); $\mathrm{Hf}$ - Holocene fluvial surface. Faceting along some ridges and bluff edges reflects absence of ground returns from laser because of thick forest canopy or deletion during post-processing.

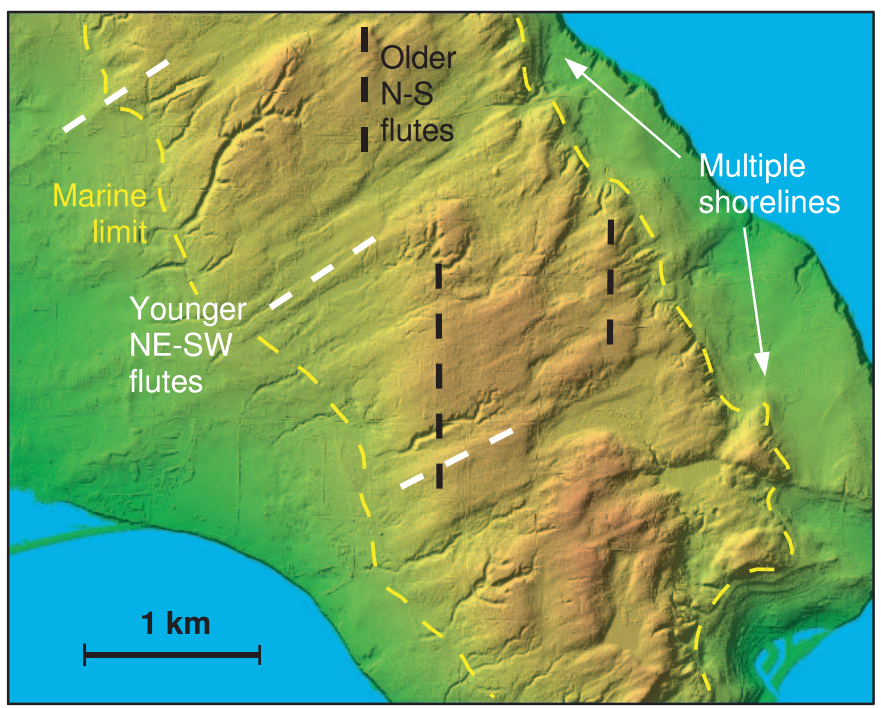

Figure 7. Lidar topography of part of Whidbey Island. Superimposed flutes record change in ice-flow direction late in Vashon glacial cycle. Note subdued surface below upper limit of marine inundation and multiple shorelines formed during postglacial isostatic rebound. See Figure 3 for location. lidar DEMs appears close to that needed to capture all of the fluvial channels in the Puget Lowland landscape. Geomorphic mapping of Bainbridge Island (Fig. 5; Haugerud, 2001) and the county in which it sits is providing an improved landslide inventory, a refined analysis of ice-marginal lake history and elevations, and an enhanced appreciation of glacial process.

Comparison with landslide inventories from conventional mapping shows that with lidar topography we are finding over twice as many deep-seated landslides (Fig 6)_and in some cases, we are able to see that certain features are not landslides (Table 1). The difference reflects the inability of air-photo-based methods to see through the forest canopy, the difficulty faced by the geologist on the ground seeking to synthesize impressions of the vegetated landscape, and our ability to enhance digital topography to improve the visibility of subtle features. Our lidar topography is not detailed enough to map the small debris flows $\left(<100 \mathrm{~m}^{3}\right)$ that comprise the majority of landslides in the Puget Lowland, but it does allow better identification of the steep slopes on which almost all such debris flows occur.

Retreating glacial ice dammed shortlived ice-marginal lakes, the largest of which extended across much of the Puget Lowland. Shorelines of such lakes are potential markers to identify young deformtion, though the late-glacial lakes were short-lived and rapid isostatic rebound caused their shorelines to move rapidly across the landscape. Limited by forest cover and the resolution of available topographic maps, Thorson (1989) was able to identify strandlines only at widely spaced large deltas formed where streams emptied into these lakes. Delta-top elevations increase northward at about $1 \mathrm{~m} / \mathrm{km}$, recording postglacial isostatic recovery of the Lowland. A kink in the delta elevation/latitude curve reflects postglacial movement in the Seattle fault zone (Thorson, 1993). With lidar topography, we see subtle nicks in some hillsides that correspond to the main recessional water levels (e.g., dashed blue line on Fig. 5). The feasibility of closely defining lake levels over large areas is uncertain until more geomorphic mapping is completed, but the possibility of defining such features throughout the Puget Lowland is exciting: we could not only thus identify Holocene faults, but we could place an upper limit on possible Holocene vertical offsets.

Detailed topography informs our understanding of glacial processes in this landscape. It reinforces the distinction between sub-parallel flutes, with meter to decameter amplitudes and spacing of hundreds of meters, and much larger anastomosing troughs (e.g., Rich Passage on cover image). Booth's (1994; Booth and Hallet, 1993) conclusion that the large troughs were eroded by subglacial melt water has not convinced all observers. The clear contrast in form between flutes, which almost certainly were molded by flowing ice, and large troughs that must have been made by another process, supports Booth's conclusion.

Thorson (1980) hypothesized that the ice front in the Strait of Juan de Fuca retreated earlier than that in Puget Sound, inducing a local change in flow direction. At the north end of Whidbey Island, lidar topography shows a change in ice-flow direction that was even more profound and more extensive than Thorson figured. Late during the last glaciation, ice flowed to the west-southwest and modified flutes formed during earlier southwards flow (Fig. 7). A result of this overprinting was general smoothing that other observers have attributed to a blanket of glaciomarine drift or widespread end moraine. Note also, in Figure 7, the flights of relict shorelines that record postglacial isostatic rebound.

\section{CONCLUSIONS}

Lidar is capable of high-resolution topographic mapping in the heavily forested terrain of the Puget Lowland, producing better results than airborne interferometric synthetic aperture radar (InSAR) (Norheim et al., 2002) and photogrammetry. We have found the consortium approach to be very successful. Lidar costs drop significantly as the surveyed area increases be- 
TABLE 1. COMPARISON OF LIDAR-BASED AND CONVENTIONAL LANDSLIDE INVENTORIES, CENTRAL KING COUNTY

\begin{tabular}{lc}
\hline \hline & $\begin{array}{c}\text { Area } \\
\left(\mathrm{km}^{2}\right)\end{array}$ \\
\hline Identified as landslide in both lidar and conventional inventories & 31 \\
Identified as landslide in lidar inventory, not identified conventionally & 123 \\
Identified as landslide on conventional inventory, not identified in lidar inventory* & 39 \\
\hline $\begin{array}{l}\text { Note: From geologic map compilation in preparation by D.B. Booth, R.A. Haugerud, and J. } \\
\text { Sackett, and analysis of lidar topography by Haugerud. See Figure 3 for area of comparison. } \\
\text { *Includes shallow debris flows on steep slopes in conventional inventory; lidar inventory is }\end{array}$ \\
$\begin{array}{l}\text { largely restricted to deep-seated features. Lidar topography suggests some landslides in } \\
\text { conventional inventory do not exist. }\end{array}$
\end{tabular}

cause of reduced mobilization expenses. By cooperatively contracting to map large areas across agency boundaries, we save money and produce a more uniform product. With lidar topography, we have more than succeeded in our goal of finding fault scarps for paleoseismic studies, we are improving our landslide inventory, and we are increasing our understanding of landscape evolution.

There is more to learn about the use of lidar mapping technology. From our experience, we see the need for better calibration procedures to increase accuracy by modeling and removing systematic errors. We need improved techniques for assessing the quality of bare-earth DEMs in forested areas. High-relief areas pose logistical difficulties; we are exploring these with a second NASA grant to survey of the west Mount Rainier seismic zone that includes over $1200 \mathrm{~m}$ of local relief. The best post-processing results are still obtained with substantial manual intervention, which raises the cost of lidar topography and, in some areas, leaves nagging concerns about the reproducibility of the resulting bare-earth DEM. Full automation is desirable. Pulse density is the prime determinant of survey cost, yet we lack the experience and tools to estimate the optimum pulse density in different landscapes.

Much work remains to be done to turn our new information on fault scarp locations into knowledge of the frequency of large crustal earthquakes in the Puget Lowland. Our present earthquake prehistory suggests that there was an unusual cluster of activity about 1100 years ago. If this clustering is real, what does it tell us about crustal deformation, the role of ice sheet unloading, and earthquake hazards (Thorson, 1996)? Or is the clustering only apparent, perhaps in part due to better preservation of younger scarps? We need research into scarp degradation rates in this setting. Work is also needed to use the improved landslide inventory to model landslide processes and improve prediction of future slope failures.

Beyond the specific knowledge we are gaining about seismic and landslide hazards and landscape evolution in the Puget Lowland, the lessons gained from this successful lidar mapping experiment should enable improved earth-science investigations in forested landscapes elsewhere in the world.

\section{ACKNOWLEDGMENTS}

It continues to be a pleasure to work with our partners in the Puget Sound Lidar Consortium. We have benefited greatly from their skills and experience. We are grateful for continuing support from the Solid Earth and Natural Hazards Program at NASA. We thank William Dietrich, Keith Howard, Robert Thorson, and Ray Wells for constructive reviews of this article.

\section{References Cited}

Blair, J.B., Rabine, D.L., and Hofton, M.A., 1999, The Laser Vegetation Imaging Sensor: a medium-altitude, digitizationonly, airborne laser altimeter for mapping vegetation and topography: ISPRS Journal of Photogrammetry and Remote Sensing, v. 54, p. 115-122.

Blakely, R.J., Wells, R.E., and Weaver, C.S., 1999, Puget Sound aeromagnetic maps and data: U.S. Geological Survey, Openfile Report 99-514, http://geopubs.wr.usgs.gov/open-file/of99514/ (March 2003).

Blakely, R.J., Wells, R.E., Weaver, C.S., and Johnson, S.Y., 2002, Location, structure, and seismicity of the Seattle fault zone, Washington: Evidence from aeromagnetic anomalies, geologic mapping, and seismic-reflection data: Geological Society of America Bulletin, v. 114, p. 169-177.

Booth, D.B., 1994, Glaciofluvial infilling and scour of the Puget Lowland, Washington, during ice-sheet glaciation: Geology, v. 22, p. 695-698.

Booth, D.B., and Hallet, B., 1993, Channel networks carved by subglacial water, Observations and reconstructions in the eastern Puget Lowland, Washington: Geological Society of America Bulletin, v. 105, p. 671-683.

Brocher, T.M., Parsons, T., Blakely, R.J., Christensen, N.I., Fisher, M.A., Wells, R.E., and the SHIPS Working Group, 2001, Upper crustal structure in Puget Lowland, Washington: Results from the 1998 Seismic Hazards Investigation in Puget Sound: Journal of Geophysical Research, v. 106, p. 13,541-13,564.

Bucknam, R.C., Hemphill-Haley, E., and Leopold, E.B., 1992, Abrupt uplift within the past 1,700 years at southern Puget Sound, Washington: Science, v. 258, p. 1611-1614.
Carter, W.E., Shrestha, R.L., Tuell, G., Bloomquist, D., and Sartori, M., 2001, Airborne laser swath mapping shines new light on Earth's topography: Eos (Transactions, American Geophysical Union), v. 82, p. 549

Danes, Z.F., Bonno, M., Brau, E., Gilham, W.D., Hoffman, T.F., Johansen, D., Jones, M.H., Malfait, B., Masten, J., and Teague, G.O., 1965, Geophysical investigation of the southern Puget Sound area, Washington: Journal of Geophysical Research, v. 70, p. 5573-5580.

Degnan, J., McGary, J., Zagwodzki, T., Dabney, P., and Geiger, J., 2002, Design and performance of an airborne multikilohertz photon-counting microlaser altimeter: International Archives of Photogrammetry and Remote Sensing, XXXIV-3/W4, p. 9-16.

Dietrich, W.E., Bellugi, D., and Real de Asua, R., 2001

Validation of the shallow landslide model, SHALSTAB, for forest management, in Wigmosta, M.S., and Burges, S.J., eds., Land use and watersheds: Human influence on hydrology and geomorphology in urban and forest areas: American Geophysical Union, Water Science and Applications, v. 2, p. $195-227$.

Gutierrez, R., Gibeaut, J.C., Crawford, M.M., Mahoney, M.P., Smith, S., Gutelius, W., Carswell, D., and MacPherson, E., 1998, Airborne laser swath mapping of Galveston Island and Bolivar Peninsula, Texas: Proceedings of the Fifth International Conference on Remote Sensing for Marine and Coastal Environments, San Diego, California, Oct. 5-7, vol. 1, p. 1236-1243.

Harding, D.J., and Berghoff, G.S., 2000, Fault scarp detection beneath dense vegetation cover: Airborne lidar mapping of the Seattle fault zone, Bainbridge Island, Washington State: Proceedings of the American Society of Photogrammetry and Remote Sensing Annual Conference, Washington, D.C., May, 2000, 9 p., http://duff.geology.washington.edu/data/raster/lidar/harding.pdf (March 2003).

Harding, D.J., Johnson, S.Y., and Haugerud, R.A., 2002, Folding and rupture of an uplifted Holocene marine platform in the Seattle fault zone, Washington, revealed by airborne laser swath mapping: Geological Society of America, Abstracts with Programs, v. 34, no. 5, p. A-107.

Haugerud, R.A., 2001, Geomorphic mapping in glaciated terrain: Lidar in the Puget Lowland, Washington: Geologica Society of America, Abstracts with Programs, v. 33, no. 6, p. A-267.

Haugerud, R.A., 2002, Lidar evidence for Holocene surface rupture on the Little River fault near Port Angeles, Washington [abstract]: Seismological Research Letters, v. 73, p. 248.

Haugerud, R.A., and Harding, D.J., 2001, Some algorithms for virtual deforestation (VDF) of lidar topographic survey data: International Archives of Photogrammetry and Remote Sensing, XXXIV-3/W4, p. 211-217, http://duff.geology.washington.edu/ data/raster/lidar/vdf4.pdf (March 2003).

Hudnut, K.W., Borsa, A., Glennie, C., and Minster, J.-B., 2002, High-resolution topography along surface rupture of the October 16, 1999 Hector Mine earthquake (Mw7.1) from airborne laser swath mapping: Bulletin of the Seismological Society of America, v. 92, p., 1570-1576.

Johnson, S.Y., Potter, C.J., and Armentrout, J.M., 1994, Origin and evolution of the Seattle basin and Seattle fault: Geology, v. 22 , p. $71-74$.

Johnson, S.Y., Dadisman, S.V., Childs, J.R., and Stanley, W.D. 1999, Active tectonics of the Seattle fault and central Puget Sound, Washington: Implications for earthquake hazards: Geological Society of America Bulletin, v. 111, p. 1042-1053. Johnson, S.Y., Dadisman, S.V., and Stephenson, W.J., 2001a, Is the Tacoma geophysical anomaly (Puget Lowland, WA) characterized by two distinct segments? Implications for earthquake hazard assessment [abs.]: Seismological Research Letters, v. 72, p. 238.

Johnson, S.Y., Dadisman, S.V., Mosher, D.C., Blakely, R.J., and Childs, J.R., 2001b, Active tectonics of the Devils Mountain fault and related structures, northern Puget Lowland and eastern Strait of Juan de Fuca region, Pacific Northwest: U.S. Geological Survey Professional Paper 1643, 45 p., 2 plates.

Krabill, W.B., Thomas, R.H., Martin, C.F., Swift, R.N., and Frederick, E.B., 1995, Accuracy of airborne laser altimetry over the Greenland ice sheet: International Journal of Remote Sensing, v. 16, p. 1211-1222.

Mazzotti, S., Dragert, H., Hyndman, R.D., Miller, M.M., and Henton, J.A., 2002, GPS deformation in a region of high crustal seismicity: N. Cascadia forearc: Earth and Planetary Science Letters, v. 198, p. 41-48. 
McCaffrey, R., Long, M.D., Goldfinger, C., Zwick, P.C., Nabelek, J.L., Johnson, C.K., and Smith, C., 2000, Rotation and plate locking at the southern Cascadia subduction zone: Geophysical Research Letters, v. 27, p. 3117-3120.

Miller, M.M., Johnson, D.J., Rubin, C.M., Dragert, H., Wang, K. Qamar, A , and Goldfinger, C, 2001, GPS-determination of along-strike variation in Cascadia margin kinematics: Implications for relative plate motion, subduction zone coupling, and permanent deformation: Tectonics, v. 20, p. $161-176$.

Nelson, A.R., Johnson, S.Y., Wells, R.E., Pezzopane, S.K., Kelsey, H.M., Sherrod, B.L., Bradley, L., Koehler, R.D., III, Bucknam, R.C., Haugerud, R., and Laprade, W.T., 2002, Field and laboratory data from an earthquake history study of the Toe Jam Hill fault, Bainbridge Island, Washington: U.S. Geological Survey Open-File Report 02-0060, http://pubs.usgs.gov/of/ 2002/ofr-02-0060/ (March 2003).

Norheim, R.A., Queija, V.R., and Haugerud, R.A., 2002, Comparison of LIDAR and INSAR DEMs with dense ground control: Proceedings, Environmental Systems Research Institute 2002 User Conference, http://gis.esri.com/library/userconf/ proc02/pap0442/p0442.htm (March 2003).

Porter, S.C., and Swanson, T.W., 1998, Radiocarbon age constraints on rates of advance and retreat of the Puget Lobe of the Cordilleran Ice Sheet during the last glaciation: Quaternary Research v. 50, p. 205-213.
Sallenger, A.H., Krabill, W., Brock, J., Swift, R., Jansen, M., Manizade, S., Richmond, B., Hampton, M., and Eslinger, D. 1999, Airborne laser study quantifies El Niño-induced coastal change: Eos (Transactions American Geophysical Union), v. 80, p. 89, 92-93.

Satake, K., Shimazaki, K., Tsuji, Y., and Ueda, K., 1996, Time and size of a giant earthquake in Cascadia inferred from Japanese tsunami records of January 1700: Nature, v. 379, p. $246-249$.

Sherrod, B.L., 2002, Late Quaternary surface rupture along the Seattle fault zone near Bellevue, Washington: Eos

(Transactions, American Geophysical Union), v. 83, n. 47, Fall Meeting Supplement, Abstract S21C-12.

Sherrod, B.L., Haeussler, P.J., Wells, R., Troost, K., and Haugerud, R., 2001, Surface rupture in the Seattle fault zone near Bellevue, Washington [abs.]: Seismological Research Letters, v. 72, p. 253.

Thorson, R.M., 1980, Ice-sheet glaciation of the Puget Lowland, Washington, during the Vashon Stade (Late Pleistocene): Quaternary Research, v. 13, p. 303-321.

Thorson, R.M., 1989, Glacio-isostatic response of the Puget Sound area, Washington: Geological Society of America Bulletin, v. 101, p. 1163-1174.

Thorson, R.M., 1993, Postglacial offset along the Seattle fault: Science, v. 260, p. 825-826.
Thorson, R.M., 1996, Earthquake recurrence and glacial loading in western Washington: Geological Society of America Bulletin, v. 108, p. 1182-1191.

Walsh, T.J., Logan, R.L., Neal, K.G., 1999, Active fault investigations on the Canyon River Fault, southern Olympic Range, Washington: USGS External Research Program, Annual Project Summaries, v. 40, Pacific NW, Award 1434-HQ-97-GR03120, 20 p., http://erp-web.er.usgs.gov/reports/annsum/ vol40/pn/g3120.pdf (March 2003).

Wells, R.E., Weaver, C.S., and Blakely, R.J., 1998, Fore arc migration in Cascadia and its neotectonic significance: Geology, v. 26 , p. $759-762$.

Wilson, J.R., Bartholomew, M.J., and Carson, R.J., 1979, Late Quaternary faults and their relationship to tectonism in the Olympic Peninsula, Washington: Geology, v. 7, p. 235-239.

Wright, W.C., and Brock, J.C., 2002, EAARL: A Lidar for Mapping Shallow Coral Reefs and Other Coastal Environments: Seventh International Conference on Remote Sensing for Marine and Coastal Environments, Miami, Florida

(Proceedings, CD-ROM).

Manuscript received March 17, 2003; accepted April 9, 2003.

\section{CORRECTION}

Reactivation, trishear modeling, and folded basement in Laramide uplifts: Implications for the origins of intra-continental faults

GSA Today, v. 13, no. 3, p. 4-10 (March 2003)
An incorrect Table 1 was published. The corrected Table 1 is shown here. GSA Today regrets the error.

TABLE 1. EXAMPLES OF FOLDED BASEMENT-COVER CONTACT

\begin{tabular}{|c|c|c|c|c|c|c|}
\hline Structure & $\begin{array}{l}\text { Location } \\
\text { (see Fig. 1) }\end{array}$ & $\begin{array}{c}\text { Basement } \\
\text { fold half } \\
\text { wavelength } \\
(\mathrm{km})\end{array}$ & $\begin{array}{l}\text { Interlimb } \\
\text { angle } \\
\text { (degrees) }\end{array}$ & $\begin{array}{l}\text { Maximum dip of } \\
\text { basement } \\
\text { surface } \\
\text { (degrees) }\end{array}$ & Source & Reference \\
\hline Island Park fault & 2 & 0.8 & 90 & 23 & cross section $^{1,2}$ & Stone, $1993 b$ \\
\hline Uinta Basin Boudary fault & 3 & 5.0 & 140 & 40 & cross section $^{1,2}$ & Stone, 1993b \\
\hline North flank, Uinta Mountains & 4 & 2.3 & 115 & 85 & cross section $^{1,2}$ & Gries, 1983 \\
\hline Anticline in Battleship field & 6 & 0.3 & 165 & 10 & seismic line $e^{4}$ & Lange and Wellborn, 1985 \\
\hline Rangely anticline & 7 & 0.7 & 80 & 75 & cross section $^{1,2}$ & Mitra and Mount, 1998 \\
\hline Twin Mountain anticline & 8 & 0.1 & 70 & $85^{\star}$ & cross section $^{5}$ & Schmidt et al., 1993 \\
\hline Big Thompson anticline & 9 & 0.5 & 75 & 90 & cross section $^{5,7}$ & Narr and Suppe, 1994 \\
\hline Willow Creek anticline & 10 & 1.0 & 100 & 80 & cross section $^{1}$ & Narr and Suppe, 1994 \\
\hline Elk Basin anticline & 14 & 0.4 & 100 & 50 & cross section $^{1,2}$ & Stone, $1993 a$ \\
\hline Maverick Springs anticline & 15 & 4.0 & 60 & 40 & cross section $^{2,5}$ & Stone, $1993 a$ \\
\hline $\begin{array}{l}\text { Small anticline on Casper } \\
\text { Mountain }\end{array}$ & 16 & 0.1 & 105 & 90 & cross section ${ }^{6}$ & Narr, 1993 \\
\hline $\begin{array}{l}\text { Five Springs thrust, Bighorn } \\
\text { Mountains }\end{array}$ & 17 & 0.7 & 85 & 65 & cross section $^{6}$ & $\begin{array}{l}\text { Narr and Suppe, 1994; } \\
\text { Wise and Obi, } 1992\end{array}$ \\
\hline Rawlins uplift & 18 & $>1.3$ & 70 & $75^{*}$ & cross section & Gries, 1983 \\
\hline Granite Mountains & 19 & 2.5 & 150 & 34 & cross section & Gries, 1983 \\
\hline LaPrele anticline & 20 & 0.6 & 70 & 90 & cross section $^{5}$ & Schmidt et al., 1993 \\
\hline Sheephead Mountain anticline & 21 & 0.1 & 60 & $75^{\star}$ & cross section $^{5}$ & Chase et al., 1993 \\
\hline Madden anticline & 22 & 5.0 & 160 & 10 & cross section $^{1,2}$ & Ray and Keefer, 1985 \\
\hline
\end{tabular}

Note: Asterisk indicates overturned; 1-seismic control; 2-well control; 3-time section; 4-depth section; 5-down-plunge projection; 6-surface control only; 7-gravity control. 